\title{
Ethical terms set for breast cancer test
}

[WASHINGTON] A team that has just been granted British patent rights on a gene whose mutations are linked to breast cancer has licensed the use of the genetic data in an unusual agreement that requires the exclusive licensee to meet strict conditions for what the team views as ethical use of any diagnostic tests it develops.

These include broad sublicensing of diagnostic tests to other concerns, a requirement for pre- and post-test counselling, and a ban on direct advertising of screening tests to the public. The use of the techniques will be made freely available to Britain's National Health Service (NHS).

The London-based Cancer Research Campaign Technology (CRCT) and its US partner, Duke University in Durham, North Carolina, have been granted a British patent for the full-length coding sequence of the gene, thought in its unmutated state to produce a tumour suppressor protein.

But the US patent situation remains open. Both CRCT/Duke and their major competitor in the race to find the gene - Myriad Genetics of Salt Lake City, Utah - have applied for BRCA2 patents. Myriad announced its move the day before the CRCT/Duke team published its discovery of the mutation in 1995 (see Nature 378, 789; 1995). A decision by the US Patent and Trademark Office is not likely for at least two years.

CRCT/Duke's rights under the British patent include pharmaceuticals, diagnostic methods and a method for producing the protein manufactured by the gene. The US company Oncormed of Gaithersburg, Maryland, has been granted an exclusive worldwide licence to the patent for diagnostic services and products.

In return, Oncormed has agreed to sublicense diagnostic tests broadly to hospitals, nonprofit organizations and commercial groups. As a condition of receiving the licence, it has granted the UK NHS a free licence to practise BRCA2 testing. "Our goal is to broadly license gene discoveries for diagnostic purposes," says Leslie Alexandre, Oncormed's corporate affairs vice-president.

One author of the Nature paper, Mike Stratton, professor of cancer genetics at the Institute of Cancer Research, Sutton, says that his group's intention in patenting $B R C A 2$ was to prevent it from becoming the exclusive province of one commercial interest. Taking out the patent was "the only way of defending the gene" and of having "some control over its future", he says.

In choosing to grant an exclusive licence to Oncormed, he says, CRCT set down four principles that the company promised to adhere to: that it would sublicense diagnostic tests to other concerns; that access to diagnostic tests should be only through doctors, with thorough pre- and post-test counselling; that no attempt should be made to "drum up business" through advertising to the public; and that the NHS, which contributed to the gene's discovery, should not be charged a licence fee.

Patricia Murphy, a geneticist at Albany Medical College in New York state and a consultant to Oncormed, says that to her knowledge the arrangement is the first of its kind. Typically, she says, "the reason you get an exclusive licence is to capture the market and prevent others from doing the testing".

But some say that agreements with private companies cannot be substituted for government regulations requiring that genetic testing be conducted ethically and responsibly. One critic is Neil Holtzman, the director of genetics and public policy studies at the Johns Hopkins Medical Institutions in Baltimore, Maryland.
Holtzman chaired the task force on genetic testing of the Working Group on the Ethical, Legal and Social Implications of Human Genome Research, established by the US National Institutes of Health and the Department of Energy. "I would not entrust a company, as apparently CRCT has done, to ensure that all testing will be appropriate," says Holtzman. "I think you need external control and review."

Stratton's group once collaborated with Myriad, but fell out with it in 1994 when Myriad filed for a broad patent on the other breast cancer gene, BRCA1, which its scientists discovered in collaboration with researchers at the University of Utah. CRCT and Stratton say that they have profound philosophical differences with Myriad about how widely available the diagnostic and therapeutic applications of patented genes should be made.

\section{NSF hires expert to tackle 'millennium bug'}

[воSтоN] Faced with the possibility of widespread computer failures on 1 January 2000, the US National Science Foundation (NSF) has hired an expert to help the researchers it funds to get through the millennial transition with minimal disruption.

Mark Haselkorn, a professor of technical communication at the University of Washington in Seattle, has been appointed to determine how ready researchers are to cope with the year 2000 'bug' and to formulate strategies to address potential difficulties. The problem stems from the fact that many computer programs and chips represent years by two digits rather than four and cannot accept that the year ' 99 ' is followed by ' 00 '. So operations based on twodigit years are likely to be fouled up.

Steve Williams, a director in the information systems division at NSF, says that, although responsibility for addressing the issue rests with grant recipients and their institutions, "the problem appears serious enough for us to offer technical assistance". He admits that the initiative is unusual for NSF, "since we normally take a hands-off approach with our grantees".

Haselkorn will not be involved with NSF's internal efforts to make sure its own systems function properly. He says his first task will be to conduct a study of user communities, with protecting data the chief objective. Priority will be given to ensuring that NSF facilities, such as telescopes and Antarctic research centres, avoid serious malfunction.

The second set of targets will be large NSF-funded research centres at universities and other institutions. Next, Haselkorn will try to assist individual researchers. "There's no way I can help every one of these people," he says. "But I hope to make information available on the web and by other means so they don't feel totally clueless."

Researchers who share data with others must ensure that changes in other databases will not disturb their own databases, says Haselkorn. They also need to figure out whether their systems are compliant. "Even if the system is capable of handling fourdigit dates, that doesn't mean it's been programmed to actually use them," he says.

An important part of his mission, he adds, will be to "show how resources can be spent more efficiently, with less effort devoted to things that are unlikely to work". Highly interconnected systems, with "data shared all over the place", are the most problematic.

"In those cases, even if you could do your own fix, the odds of other parts of the system being fixed on time are vanishingly small," Haselkorn says. "So you might want to take a different strategy, thinking instead about how to mitigate the impacts."

Haselkorn is chairing a committee charged with writing a technical information statement on the issue for the US Institute of Electrical and Electronics Engineers. The report is due for release in January 1998.

NSF hopes that Haselkorn will help to dispel some of the myths and hype surrounding the year 2000 problem. "We're trying to alleviate fears that this will be a major catastrophe, and instead take steps to deal with the issue in a level-headed way," Williams says.

Steve Nadis 